\title{
NORTHERN FLYING SQUIRREL AND RED BAT CAUGHT ON BARBED-WIRE
}

ROBERT W. NERO, Box 14, 1495 St. James Street, Winnipeg, Manitoba, R3H OW9

A recent review of accidental entanglement of birds on barbed-wire fences lists 41 articles on the subject. ${ }^{1}$ Included in the more than 40 species noted were eight kinds of owls, the Great Horned Owl being found by seven observers. As the authors point out, not all of the birds involved with collisions with fences are likely to be found, hence "the full impact of fence-related mortality would be difficult to assess."1 Mammals are not expected to become caught on barbed-wire in the way that birds are, except, as noted in the literature for bats. ${ }^{2,3,9}$ We can add another case of bat mortality in this way: Peter Taylor found a mummified Red Bat (Lasiurus borealis) snagged by its tail membrane on the barbed-wire high atop the perimeter fence at the Atomic Energy of Canada plant at Pinawa, Manitoba, on 10 September 1992.

On 8 October 1992, while walking along the edge of a grazed woodlot about $6.4 \mathrm{~km}$ northeast of Haywood, Manitoba, I found the remains of a Northern Flying Squirrel (Glaucomys sabrinus) hanging on a fence roughly $1.5 \mathrm{~m}$ from the nearest trees. It took me a moment to realize that it was not simply an old rag, for I had not expected this species to occur in these sparse woods. The squirrel was dangling from the top strand of wire, about $1 \mathrm{~m}$ above the ground, near a fence post. It was not easily unhooked. The squirrel had caught itself on a barb through the skin in front of its right forearm. The dried carcass, a husk of skin and bones, clearly had been there for some time. The woods consist of Trembling Aspen and Bur Oak growing on sandy loam. The fence ran parallel and close to a gravel road, across which was a more mature stand of aspen, also grazed.

According to Soper, the subspecies of flying squirrel expected to occur in this region is Glaucomys sabrinus canescens, his "Pallid Flying Squirrel."6 The type of locality for this pale race is Portage la Prairie, only about $30 \mathrm{~km}$ northwest of the site where I found the dead squirrel. This race is "known to inhabit the full length of the wooded valleys of the Red River and the Assiniboine, west to at least Treesbank, and south through the Pembina Hills and other timbered tracts into North Dakota." The present record shows that flying squirrels can occur in small tree growth at a considerable distance from the more heavily wooded river valleys.

A recent highly informative book on both Northern and Southern Flying Squirrels refers to but one previous record of a Northern Flying Squirrel caught on a barbed-wire fence. ${ }^{7}$ I went to the original publication for details of this observation 
which was made on 20 June 1944 in the Upper Peninsula of Michigan. ${ }^{5}$ The squirrel, an adult nursing female, was not long dead and had been trapped by a barb through the membrane in front of the left hind foot. "On attempting to free itself the squirrel had spun around the wire several times thus wrapping the skin further around it and making escape more hopeless. The skin at that point was badly torn. The incisors were broken down, evidently from futile assaults upon the metal. The wire was about three and a half feet off the ground. ... I could not see any sizeable trees toward which the squirrel might have been aiming unless it was one of the numerous saplings. The squirrel must have been nearing the ground at the termination of its glide and struck the fence where it perished." Mammalogist T. Donald Carter found a Northern Flying Squirrel that had died in similar fashion north of Jasper National Park, Alberta, presumably in 1935: "A dead immature individual was found by Mr. Carter firmly snagged on a barbed-wire fence by its flight membrane."

Another rare accident involving a Northern Flying Squirrel that survived came to light after an adult male was accidentally trapped on 3 January 1975 near Gypsumville, Manitoba. "The flying squirrel must have glided into a branch of a Balsam Poplar tree, whereupon the slender and sharply-pointed terminal bud penetrated the loose thin skin and lodged itself along the rib cage. ... The winter bud probably entered the body during the autumn, or possibly even during previous winter." ${ }^{10}$

Nancy Wells-Gosling's wellillustrated book on flying squirrels points out that in North Carolina, at the southern border of this species' range, the Northern Flying Squirrel is listed as endangered. ${ }^{7}$ Not, we hope, by barbed-wire.

I would like to thank Peter Taylor and Jack DuBois for the information on the Red Bat. Robert E. Jones reviewed the manuscript and helped with references.

1. ALLEN, G.T. and P. RAMIREZ. 1990. A review of bird deaths on barbedwire fences. Wilson Bull. 102:553558.

2. BANFIELD, A.W.F. 1974. The mammals of Canada. Natl. Mus. Natural Sciences, Natl. Mus. Canada, Univ. of Toronto Press, Toronto. 438 pp.

3. CAHALANE, V.H. 1954. Mammals of North America. MacMillan Co., New York. $682 \mathrm{pp}$.

4. CROWE, P.E. 1943. Notes on some mammals of southern Canadian Rocky Mountains. Bull. Amer. Mus. Nat. Hist. 80:391-410.

5. FINDLEY, J.S. 1945. The interesting fate of a flying squirrel. Journ. Mammology 26:437.

6. SOPER, J.D. 1961. The mammals of Manitoba. Canadian Wildlife Service, Wildlife Mgt. Bull. Series 1, No. 17, Ottawa. 51 pp. (Reprinted, with added index, from the Can. Field-Nat. 75:171-219.)

7. WELLS-GOSLING, N. 1985. Flying squirrels: gliders in the dark. Smithsonian Inst. Press, Washington, D.C. $128 \mathrm{pp}$.

8. WELLS-GOSLING, N. and L.R. HEANEY. 1984. Glaucomys sabrinus. Mammalian species 229:1-8. American Society of Mammologists.

9. WISELY, A.N. 1978. Bat dies on a barbed wire fence. Blue Jay 36:53.

10. WRIGLEY, R.E. 1975. Poplar bud in the subcutaneous tissue of a Northern Flying Squirrel. Can. Field Nat. 89:466. 